\title{
'Stalking the stalker': a Chwezi initiation into spirit possession and experiential structure
}

Koen STROEKen University of Leuven

\begin{abstract}
Among Sukuma (Tanzania) the Chwezi spirit society operates in the shadow of, and in tension with, the lineage cults domesticating the dead. As this ethnography describes, Chwezi candidates are initiated into spirit possession by 'stalking the stalker', that is, by seeking synchrony with intrusion. Recognition of the healing and of the power/resistance in spirit performances once resuscitated anthropology from its crisis of representation, but now arrests advance. Both functions obscure possession itself, which, unlike rituals, has a subversive, 'quaternary' structure that reveals the gap between experience and communication, and thus decentres both self and society. Spirit possession exposes the plurality of experiential structures. This may better account for its role world-wide in dialectics of social resistance and of cathartic healing.
\end{abstract}

The Chwezi ${ }^{1}$ tradition has largely been overlooked in the literature on spirit possession and healing. The reader will discover more than one reason why this initiatory complex from inter-lacustrine Africa deserves to stand next to well-studied spirit societies such as the Bori and Zar that are more wide spread on the continent. Besides enriching the ethnographic record, the Chwezi initiation, as it is performed today among Sukuma in northwest Tanzania, introduces newcomers of different backgrounds to the meaning of possession and this in a manner approved and perfected over centuries by experienced spirit mediums. The conclusions draw on two years of qualitative research among Sukuma agro-pastoral farmers and mediumistic healers, on initiation into the Chwezi cult in 1997, and on further participations in 2000 and 2003.

\section{The strategic, the cathartic, and the spirit}

If spirit possession seems destined for anthropological research, in its attention to otherness and its respect for the integrity of that otherness, it never was anthropology's crown subject. The first theoretical frameworks came from psychology and sociology, objectifying mediumistic practice in terms of abnormal mental or social conditions (e.g. Bourguignon 1973; Lewis 2003 [1971]; Métraux 1972 [1959]). Critique of such objectivism, and a concomitant crisis of representation, marked our discipline from the 1970s. From it grew interpretative approaches, of possession, among others, which elicited the symbolic system from a culture-specific perspective (Lambek 1981: 5). Most 
of these, in turn, ignored the broader socio-political conditions from which any medical practice arises (Good 1994: 56). Bourdieu's concept of the habitus soon appealed for an explicit combination of these socio-political conditions with culturespecific dispositions (1980: 51-87).

The interest in this combination was to place a once badly served subject at the forefront of anthropological debate. Possession practices appeared to exemplify both the political and the culture-specific strand while providing new insight into classic texts. Cults of mediumship were approached as local strategies of power and resistance, for example against postcolonial subordination (Comaroff 1985; Giles 1987; Kapferer 1997; Sharp 1999; Werbner 1989) - if more actively strategic than the protest against confinement which Lewis (2003 [1971]: 91) recognized in Sudanese women's possessions. The second paradigm dominating the 1990s was that of embodiment, against objectivism (Boddy 1989; Csordas 1995; Devisch 1993; Fernandez 1991). The student of possession appeared ideally placed to discuss the healing, cathartic dimension of culture-specific embodiments, as prefigured by Victor Turner's and much earlier Van Gennep's famous dialectic of ritual.

The literature's favourite paradigms, power and healing, are not irrelevant to the way in which Chwezi mediums tend to structure their often puzzling experiences. As for healing, the spirits are spoken of as previously initiated ancestors who want the tradition to be continued. Until compliance, the descendant will suffer from infertility, inexplicable tiredness, chronic pains, lack of zest for living, frightening dreams, hearing voices, insomnia, autistic or uncontrolled behaviour. A second concern of the participants is strategic. They transfer three goats and money to the cult's regional leaders (bakingi) and lower-ranked district chiefs (batemi), who divide the proceeds among the membership. One of the teachers receives a cow and becomes the novice's 'parent'. As is true of the many associations in Sukumaland, an internal hierarchy and solidarity exists by means of which one climbs ranks through gifts and thus increases one's personal sense of power.

A contradiction surfaces, however. In explaining possession in terms of strategic and therapeutic effects, we attribute to it the purposive action that, as Crapanzano warned, 'may very well be precluded by the spirit idiom itself' (1977: 29). Does reference to functions such as resistance and healing not mean rejection of the possessed's belief in an agency of its own called spirit driving him or her? The dilemma is that if we proceed from the so-called 'fact' of spirit agency (see Turner 2004: 55; Willis 1999: 116), we again objectify the local view in the positivist terms of a truth-claim. Following Janice Boddy's (1994) seminal review, which voiced general discomfort with functionalism, the solution has been a performative model which avoids the positivism of truth-claims and limits itself to the expressive dimension of practices.

In support of this performative model, I must point out that the Chwezi terms for spirit ('the provoked one', 'the director', 'the stalker') derive from the subject's experience and not from claims about the existence of a separate category of beings. A performative account of spirits, however, ignores the participants' experience at some stages in the rite. At times when the spirit is said to enter, power and healing are irrelevant. The paradigm of healing (and embodiment) had the merit over the paradigm of power that it decentred the self and allowed social practice to be more than strategies deployed by selves against others. Healing rituals generate ternary sensations of fusion by mediating binary oppositions of the social order such as life and death (Devisch 1993: 277). However, as in Bourdieu's concept of habitus, embodiment 
explains the socialization of the body. Embodiment helps us to see possessions decentring the self but not how they might decentre society. What characterizes spirit possession, and distinguishes it from ritual, is the decentring of both self and society. Possession has a quaternary structure, summed up in the Chwezi expression of 'stalking the stalker'. Rather than being a higher form of perception, the mystical sensation consists in accepting something unsettled and resisting fusion, which sustains the passionate search between subject and spirit. Possession by a spirit is to embrace the very thing that society deems intrusive, instead of expelling or domesticating it like healers do to redress social order. That is what makes the spirit's intrusion always to some extent socially subversive, indeed disembodying, whether taking place in a cult at the centre or at the periphery of society. How to reconcile this 'subversive disembodiment' with the two functions discussed in the literature? In losing consciousness, speaking apparent non-sense, or effacing the self, the possessed paradoxically signals expansion of consciousness, sense, and self. How might loss of control be beneficial? We know that a fit of anger can happen to serve in asserting one's rights. Or, thinking of romantic seduction, the fact that an expression of passion (to paraphrase Lienhardt's (1976) notion of spirits as passiones) is uncontrolled does not preclude cathartic and even strategic benefits.

The only way, I submit, to lift the study of possession out of the instrumentalist framework its ethnographers have been struggling with is to adopt the wisdom of practices, namely to permit the plurality of experiential modalities. Inspired by Jackson and Karp's (1990: 17) reference to William James's pragmatic definition of truth, I approach the models in literature, those of power, therapy, performance, and spirit intrusion, not as conflicting claims of truth but as distinct modalities of experience. They are equally relevant during practices of possession, albeit at different moments. The Chwezi novices are not taught religious beliefs. They acquire intersubjective frames which in other contexts Goffman (1974) and Bateson (1990 [1972]: 184) have discovered to organize individual experience and which revive Dewey's old notion of 'experiential structure'. The attractive suggestion is of reconciliating phenomenological and structuralist approaches. To be of interest to a cult, the experience of spirit possession cannot be purely subjective but must have some structure that is intersubjectively conveyable and reproducible. The following study points to instances when the Chwezi articulate these structures of experience.

\section{The Chwezi myth}

Comparing myths, initiation rites, and historical records of migration and chieftaincy in the interlacustrine region of central Africa, Luc de Heusch (1966: 249, 298, 362) concluded that the Nyoro musegu, the Rundi ikishegu, the Rwandese, Ha and Ankole imandwa, the Luba mbudye, as well as the Nyamwezi and Sumbwa swezi are mediums of spirit cults that have their common root in the legendary Kitara empire of the fifteenth century. Stretching from west Uganda to northwest Tanzania, this Bantuspeaking empire was governed by a people relegated since to mythic memory - the Chwezi, famed in the area as the founders of sacred kingship. The dynasty no longer exists. Archaeological evidence on the sites of Bigo and Ntusi in Uganda suggests the existence of fortresses against Nilotic invaders from the north and other traces of cultural institutions that strongly parallel those of the Zimbabwe-Monomotapa civilization, whose origins date back to the eleventh century and whose cultural roots are assumed to be Ethiopian (Heusch 1966: 19). The golden era of the Chwezi dynasty was 
abruptly put to an end when the Nilotic Hinda belonging to the Bito clan of the Luo people took advantage of internal conflicts over royal succession and invaded Kitara to chase King Wamara. The Hinda massacred the Chwezi people, who fled with their king to the south. Mythical lore of the interlacustrine region, addressing the trauma of defeat and genocide, recounts how the survivors threw themselves in the lakes and volcanoes, and since that day visit the initiated (Heusch 1966: 37).

In a Sukuma-Nyamwezi version of the myth, the last Chwezi king transferred his cattle to his brother Ryangombe, who, after the invasion, founded a spirit cult within which rebels would regularly gather around the Erythrine tree, symbolizing both royalty and immortality (Bösch 1930: 202). Vansina (2004: 39, 220) describes 'the cult of Ryangombe' as consisting of territorial congregations that cross-cut the lineages and whose Chwezi 'demi-gods' could defeat the evil spirits of the lineage. The congregations were voluntary, egalitarian, with women playing a leading role. Vansina's reference is Berger (1981: 22, 68) on the history of religion and resistance in Uganda and Rwanda, which in turn relied on de Heusch's study cited above. The latter's main source about the Chwezi cult is Cory's (1955) account of the initiation in a sub-group of the SukumaNyamwezi linguistic and cultural complex. This paper on 'the (Bu)Swezi' is, in both ethnography and local vocabulary, probably the least accurate of Cory's studies on Sukuma associations. And remarkably, no first-hand account of the Chwezi initiation has been published since. In the literature the false impression reigns today of a cult that has disappeared in the various cultures it used to span.

How is it that a vibrant Chwezi group is to be found among Sukuma in Tanzania? The initiated have always kept their Chwezi identity to themselves, operating on the fringes of society, far from any establishment rivalling with colonial or governmental powers. Moreover, numerous other peripheral associations, of which membership can be accumulated, have since long flourished in the open society of the Sukuma, itself the result of centuries of Bantu and Nilo-Hamitic intermarriage. Sukuma farmers and herders supplement the fairly aloof national government with one of the country's most autonomous informal systems of decision-making and social control, permeated with healing traditions (Abrahams 1987: 179). Christianity and millenarian churches have little success here in comparison to neighbouring regions. With final authority vested in the (patrilineal) extended families, this society stimulates plural, non-exclusive beliefs and practices, underpinned by separate male and female social networks.

In town I heard the Chwezi described as 'witches'. There were rumours of public coitus during initiation, a large dose of secrecy, obscene language, strong black magic, and stories of robbers who succumbed after finding the shishingo diadem, sign of Chwezi membership, in their loot. The cult retorts in travel songs echoing across the valley at dusk when members walk to an event. The lyrics reassure the public that the cult of Ryangombe is more benevolent than widely accepted dance groups such as Goyangi (snake-charmers) and Nunguli (porcupine-hunters) with their magical battles: 'Let me subsume those two cults of pacification, Lungu and Cheyeki, under my cool ones. Ryangombe! [×2] The Goyangi and the Nunguli, and the Beeni? Not those. They only perform dances. They do not heal people'. The song emphasizes healing according to the long-standing Sukuma-Nyamwezi tradition of pacification (maholelo). That tradition, Tcherkézoff (1985) has demonstrated, boils down to a symbolic expulsion of the dead. This means that the public song conceals what the cult's anthem deems essential: nobody can be cured of spirit mediumship (bumanga), 
this special connection with the dead. The community's healing tradition, and the corresponding anthropological paradigm, has its limits. The Chwezi cult offers no less than an alternative to remedy, as its anthem indicates:

$\begin{array}{ll}\text { Bumanga butashilaga. } & \text { Mediumship does not die. } \\ \text { Bushila ilelo, isamva lyushila. } & \text { What ends today is the spirit's anger. }\end{array}$

Repeated in a conjuring tone, these words establish a distinction between the experience of therapy - the patient's symptoms equal the spirit's anger, which will disappear after the descendant recognizes him/her - and the experience of possession, which refers to a life-long, mediumistic disposition. Initiation does more than expel, but is not yet the alternative to therapy envisaged by the anthem. As described next in the ethnography, the 'reached' novice is handed over to a complex agency no ritual can command. Chwezi candidates therefore wear a bracelet called 'mind-shifter', ngalike, from the verb kugalika, 'to change one's mind'.

Do we recognize variations on this mind-shift the world over, from mystical to shamanic experience? The existence of such an underlying structure could explain why spirit possession unites Chwezi members with diverse cultural and linguistic backgrounds, and probably did so even before the emergence of the dynasty of the same name. In fact, a shared experiential structure is the basis I have as an outsider to justify my entering the cult. Insiders welcomed me by saying that the spirit comes in many forms. As my teacher Ng'wana Hande put it: 'Some Chwezi are like me. The spirit does not mount me to speak. It simply weeps. That is how I carry the spirit'. Few of the initiated mature into professional mediums. However, when pressing the question, heeding Wim van Binsbergen (1991: 336) on faking a vocation, my answer would be that I could not - I choose my words - 'stop myself' from becoming a Chwezi once the occasion presented itself. First, there was the momentum of accumulating memberships, which turned out to be a common reaction among my friends in the village after completing our ihane ceremony for elderhood. It perfectly suited my ethnographic ambitions. Besides this acquired taste for empowerment, there was the belief that healing requires initiation into a therapy cult. My Sukuma collaborator and friend, Paulo Makufuli, sought in Chwezi membership a radical response to witchcraft after events we had mourned over together. One of the things I learned from living with Paulo and from working with his father's younger brother, Lukundula, a renowned healer in Misungwi district, was that affliction is something transcending individuals. Paulo wanted to end the spell he believed we were under. I deemed our joint Chwezi initiation a fitting completion of our two-year journey among healers training us to divine, prepare medicines, and placate spirits. Thirdly, strategy and catharsis are one thing, but what about the spirit? With the trepidation of someone knowing how elusive such claims are, and how easily they are disparaged, I will suggest that I have been receptive to the spirit. Just when I thought I would have to fake, I did not.

Still another matter is the right to report about the initiation. The head of the Chwezi society, Ng'wana Kapini, was difficult to approach. But he lived in a village nearby and knew about us from the ihane meetings we had attended in the area. In an interview I recorded on tape he discussed the different stages of the Chwezi ritual, while holding back what the cult considers secret. He knew my intentions were to publish. Ng'wana Kapini passed away eight years ago. Our interview dictates the data I present here. When he told us that some people enter the cult for the strong protective medicine 
'ending all witchcraft', Paulo assured him that we were of that kind. An initiation ceremony had already been planned for the next month. He would notify us of the council's decision. Soon after the interview we received the good news.

\section{Spirit initiation: reached and dropped}

One late afternoon, on 25 May 1997, the Chwezi party arrived by foot at our home, singing and drumming. Their number and conduct were impressive. They simply took over our compound and intervened in the ongoing household activities. There were neither greetings nor rules of reserve. Gone was the reciprocity in earning hospitality which I had been used to with guests. Those who did gesture to greet called me 'Of the big vagina' ( $N g^{\prime}$ wa ninyo) and said ntombo (coitus) to mean ntondo (tomorrow). Paulo and I were made fools of, not taken seriously in our own home. We had become novices, denuded of accountability. The young guards (bashilikale), especially, were adept at keeping up the unique ambience of what to us seemed transgressive. They also kept the group in tune by playing the drums, to which dancing elders joined in at will.

The guards are men and women elected for the occasion to carry spears and to wear the cult's characteristic shishingo diadem all through the ceremonial period while respecting the food taboos of fish, beans, and sweet potatoes. On the first day the novices are abducted and brought to the hamlet of the leading cult elder, addressed as malamala, 'the completing one'. Just after sunset the guards circumscribe and protect the initiatory grounds against sorcery, without which, it is said, witches would take advantage of the vulnerability of the ritual's participants. The Chwezi are known for their protective medicine named 'the end', lushilo, which is to be inserted inside and around the homestead. 'The end' keeps at bay everyday magical attacks. Undressed and blindfolded with a leopard skin, the leader of the guards kneels on the ground, digs a hole with his spear at the shigiti, a small tree-shaped constellation of medicinal vessels, and burns 'the end' with a bundle of dried long grass. About every thirty feet, the guard inserts the black concoction in the ground outside the fence. A magically circumscribed space is created within which all is safe.

From the first night the most talented mediums engage in a mastered form of trance, outside in the public space of the cult's compound, accompanied by singing or drumming. Novices about to get entranced will be moved inside the house. During possession the Chwezi spirits are asked to announce their name and, if possible, to express their demands. The 'meaningless growling' (ku-lunduma) of the novice has to mature into words. In an analogy with learning drum and dance patterns, the newcomers start by mimicking what they perceive, to eventually enter into synchrony with the rest. Until sunrise, for five days in a row, the sultry air of the hut will be filled with singing interrupted by spontaneous possessions. Bodies jam-packed together, the novices become 'reached by the ancestor' (wa-shikilwa n'isamva). The following song significantly depicts possession as a reciprocal process of 'stalking' the spirits, who themselves are busy stalking the novices. Feeling in synchrony with what intrudes: how else could something be instigated that cannot be commanded?

$\begin{array}{ll}\begin{array}{l}\text { Nguno ya mahugi? }[\times 2] \\ \text { Nene ili isamva nalibinishiwa lya } \\ \text { shibyalile shane. }\end{array} & \begin{array}{l}\text { The reason for the call? } \\ \text { I have been played upon by an ancestral } \\ \text { spirit of my lineage. }\end{array} \\ \begin{array}{ll}\text { Hangi, wigele ungi, nani wa } & \text { If another appears, one of meaningless } \\ \text { igunga, kilinda buhile. Tugemage, } & \text { growling, then you should wait until it is } \\ \end{array}\end{array}$

Journal of the Royal Anthropological Institute (N.S.) 12, 785-802

(C) Royal Anthropological Institute 2006 
mulanoga ukusuutila Lusuutila. Nene natonga. [×4] tired of stalking the stalker. I go first.

Shaking shoulders and low-pitched cries (ku-huma) signal the commencement of spirit possession. The spirit announces itself as a 'great snake' (liyoka). Sukuma understand by 'the snake' the spine, which harbours the life-principle and will lodge the medium's incoming spirit. Convulsions start at the spine. The spine urges the novice to dance, which can spill over into possession.

\begin{tabular}{|c|c|}
\hline Liyoka lya maholelo & The great cooling snake emerges \\
\hline likwisengaga & \\
\hline ulu gwabala ung'weeji. & when the moon appears. \\
\hline Likunenhelaga amang'weeshing'weeshi & It instils pains \\
\hline uku ngongo. & in my back. \\
\hline Mumho lyazunyaga. & Maybe it has accepted. \\
\hline
\end{tabular}

The medium depends on the snake's goodwill and on the moon cycle. Soon the novices learn that something more than the expulsion of evil is going on. They are told to 'take care of' ( $k$-langhana) their spirit, to give it attention, and to cultivate a sense of timing. Their coinciding with an intruder left untamed is an alternative to remedies seeking to end the intrusion and pacify through ternary mediation. The travel song's emphasis on pacification makes clear that the cult does not expect the uninitiated public to grasp the quaternary structure behind Chwezi experience. The risk in singing about the alternative to remedy is, given the common opposition of social order and witchcraft, that one becomes categorized by outsiders as a witch.

To understand, we first needed to get 'reached' and 'dropped' in a séance to assess the extent of our Chwezi vocation. During the interview the malamala had surprised Paulo and me by placing all emphasis on this opening ceremony which would take place the day after arrival. Kugwisha mshishi means 'causing the reached to fall'. We were told that the condition for healing is fulfilled once the initiand has lost consciousness, which Sukuma describe as 'the heart falling'. The spirit feels recognized and thus his or her anger recedes, and with it the descendant's symptoms. (Only after involuntary possession does the possibility of controlled mediumship arise.) As in the contingent 'yes' or 'no' of a divinatory throw, it suffices that an extra-human presence is experienced. Then, as the malamala told us: 'The reached ones smile. They are healed because you got hold of them'. Once the spirit has been let in, the four to seven days of rites following are 'just rounding off'.

Both in the divination techniques Paulo and I learned from healers and in the ihane ceremonies we completed to join the society of Sukuma elders, the checking of the ancestral presence on the rooster's spleen had been a solemn occasion. But in this ceremony the oracle would be our own body. Many Chwezi songs warn about faking possession: 'If you are pretending, oh, it will destroy you. People will say it is plain madness' (Ulu wita makaala, yi, lyukupilingitya. Buyuhaya lilusalo). Before the event, the fairly young master of ceremonies (kanumba) had a word with the two of us. He ordered us to take the first two turns. When the time was ripe, he said, we had to fall down on the ground, even if there was no actual possession taking place. He gave the same advice to another novice, whose turn would come after us. Apparently the most pronounced cases of mediumship were kept for the end of the ceremony. Thinking back to the song's warning, the three of us seemed rather destined for 'plain madness'. 
But perhaps he had underestimated how much the general ambience had affected all of us, thanks to the supportive attitude of our teachers and fellow novices, the sparkles of ecstasy that had filled the air since the previous night, and the reassuring observation that, irrespective of seniority or rank, some Chwezi members are more adept at spirit possession than others.

After the rank-holders had divided the meat and beer offered by the novices, it was time for each of us to take our turn and step out of the circle where we had been waiting in the hot afternoon sun. All attention was on that one person, led into the darkness of the house and placed on the traditional round stool to become mshishi, a 'reached one', derived from the verb $k u$-shisha, 'to make arrive'. The stool, low and encompassing the buttocks, refers to the ancestor, both as a source of authority (the word 'stool', isumbi, is used for rank) and as a transitional space between life and the grave (healers are buried with their stool split in two). To protect the possessed in their vulnerable state of receptivity, a black concoction is smeared on top of the head, inside of the forearms, chest, armpits, and under the feet. Closely encircled by teacher and disciples, the candidate clenches a tiny bundle of dried long grass in both hands at chest height. A wooden stick supports the feet. In this way the body remains in suspension, separated from the ground and demarcated by the two main constituents of the bush in their sapless state: a log of wood and cut grass, two natural materials which, besides recalling death and regeneration, represent the two main ranks of power in Sukuma societies (ngogo and sanzu, respectively). The thrust of the rite - attraction of the spirit - is made material by the tying around the novice's stool of a string of small branches of the plant called luduta, 'the pulling' (from $k u-d u t a$, to pull). To further attract the spirit, a shishingo diadem, containing the secret root of mediumship, is held above the fontanelle. The 'climbing' (kubuula) of the ancestral spirit commences as the teacher sounds a small portable drum twice at the forehead, fontanelle, and back. The small space of the hut gets packed with singing, drumming, and rattling disciples calling up the ancestor, enclosing more and more upon the novice. The incantations, rattle-shakes and drumming intensify once the novice gives the impression of losing control, the shoulders shaking to rhythmic, ever louder, higher-pitched growls. 'Nyabalenge, you become like a bow straightening', the song summons over and over again (Nyabalenge, ubangile buta ukangoola). The mshishi gradually leans backwards until falling to the ground. The music stops and she screams or speaks. Assistants then carry her to a room next door, where her name is repeated until consciousness is regained.

Just like the others, I found myself in that room, repeating my name to the teacher's question 'Who are you? Did we do you wrong?' I was confused and could not stand up immediately. My legs and arms felt lame and I had to hit them to get the blood circulating again and raise myself. Paulo asked me what had happened. When I staggered out of the house, I became aware of a sharp pain in the left temple. There was a marked swelling. I could not remember whether my head had actually touched the ground while leaning backwards. In the central courtyard sounded a song to welcome 'the reached ones'. We had learned it the previous night.

Baba, unene nilabilaga, ng'wana Bugeke, nabahila. Banhu bakasalaga.

Watushiga, umani wa mazwanoge, watuleka. Bukuyombaga uboongo.
Father, look at me, child of Bugeke, I have spoken in voices. People are going mad.

He has left us, the expert of medicine, he left us to ourselves. The mind goes on speaking. 
Untwe gwasebile.

Lwabi lwane.

Waibuta inghingi iyo yanijamyaga.

Waibuta imbeho iyo nikingijaga.

Iki naluha. Bupina buluhi.
The head has been mingled with.

It has become mine.

You have cut the skin that concealed me.

You have cut the shade that protected me.

Therefore I am suffering. Deep sorrow.

Once 'dropped', we were barely given time to recover. As mere vehicles for the deceased, the novices are at this stage treated like animals. Crawling over the ground and chased by the guards, we were ordered to repeat our morning routine of licentious verses: 'The thing got stuck going in the anus', 'The clitoris drops by lack of lovers', and 'The sun is burning. Let's plant lentils in the vagina'. An ambience of threat and uncertainty ruled. We were prohibited to stand up or wash our hands before eating the few unpeeled sweet potatoes that the cooks had reserved for us. Lying on the ground, hungry and deprived of shade, we stared at the Chwezi enjoying their meals and once in a while throwing picked bones at our feet. Nothing more was needed for us to be longing for the next phase of the ritual in order to end the unaccomplished condition in which we found ourselves, and regain the consciousness lost.

\section{Interlude: on subversion}

This has puzzled me ever since. I lost consciousness, remember nothing, and yet afterwards felt something significant had happened to me. Paulo and I stared in fascination at our fellow initiands, who, just like Bugeke's child in the song, had had their protective shade 'cut' and nevertheless sang that this intrusion revealed the 'me' their skin had been concealing. Their subjectivity emerged only now, paradoxically at the moment of disembodiment. Spirits possess one person at a time. They exhibit, for all to see, the discontinuity between subjective experience and its expression in collective codes such as language and ritual. Those sensitive to the gap cultivate it. Their hint at individual freedom is 'subversive', given local conceptions of social order. If holistic concepts of Bantu sociality seem contradicted here, it is precisely because possession is exceptional, rather than representative of African society, and because it concerns the very crisis of that sociality. A study in terms of experiential structures allows for a dynamic understanding of culture that can account for an individual's shift of experience without having to suspect cultural contradiction.

The subversive nature of the experiential shift shows in the cult's breach of Sukuma conventions. Sexual segregation is suspended. Men and women wash together, sit and eat together. Conversations freely explore otherwise restricted themes such as comparisons of male and female sexuality. The cult's activities disregard clan and village life where public release of emotion is unacceptable. The pinnacle, revealed in the next section, is a symbolic denial of the incest taboo, which led de Heusch (1966: 361) to associate the Chwezi with transgression, black (versus white) magic, and a counter-order.

Now it could be objected that Victor Turner's famous concept of 'anti-structure' in ritual applies here and that taboos are also transgressed in the inversions of social order during Sukuma dances and carnival. Focus on drama, metaphor, and performance has difficulty indeed in differentiating possession from ritual or dance. In my experience the reached one does not perform. Moreover, the subversion of social distinctions is a permanent feature in Chwezi groups rather than the pivot in a ritual dialectic. The dancer's violation of social order takes place between the brackets of an appropriate 
space-time (every Sukuma is a dancer at some point in life) whereas the possessed is driven by a condition of crisis, involving a loss of self, which he or she embraces just as society would be screaming for redress. The spirit decentres both self and society. What looks like inversion, a ludic play of binary structure, is in fact a quaternary structure of enlived subversion, in which the medium's experiential shift is pivotal. The failure of binary codes to capture possession as such appears in de Heusch's (1971: 235) distinction between exorcism and adorcism, where the incoming spirit will either be expelled or domesticated but the self stays put and unaffected as if never really possessed.

Picked bones were thrown at us. Obscenities were forced upon us, more terrorizing than funny. Treated as the negation of society, we presented the protracted version of possession, exhibiting its subversive side. Only one travel song dares publicly to allude to this, in tacit yet unmistakable fashion. The song singles out the Chwezi cult as transcending the two medicinal affiliations, Galu and Gika, which divide all cults. ${ }^{2}$ This structural repositioning illustrates what I mean by subversion: not a particular line of thought, usually counter-hegemonic, but a structure of experience, which surfaces throughout the literature. ${ }^{3}$ The underlying structure means that spirit possession does not intrinsically support local cosmology or break with it in the name of modernity. It duly nuances Wim van Binsbergen's opposition (1991: 308) between the Sangoma cult and the Churches of the Spirit in Botswana. More support can be found in Janet McIntosh's recent 'counterpoint to those studies that celebrate possession's subversive overtones' (2004: 92). She expects those overtones to refer to a particular line of thought, as in Boddy's thesis on embodied counterhegemony, which she cogently challenges with the fact that Giriama spirits in Kenya on the contrary embody Muslim hegemony (whose oppression of local beliefs is lamented in interviews after the séance). Yet, McIntosh's observation of (involuntary) possessions by a reprimanding Muslim spirit confirms that the message staged is an experience of crisis, otherwise left inarticulate, and thus that her counter-example also displays the structure of subversion. I do not have the space here to discuss the personal crises preceding Chwezi-hood, but this song about women's fate is indicative of the emotional release the night before kugwisha; and how songs can spill over in spirit-led convulsions from the spine.

\author{
Makaya malambu, baniki. \\ Ukumona ng'wiyo, waliitenganije \\ mpaga lyugwilwa milage, \\ Wakoyagakoyaga yii. \\ Ng'wana wa bukwingwa, kanituulile \\ wanzuki mpaga niisikie.
}

\author{
Difficult homes, girls. \\ To see your friend, how she empowered [the \\ home] to the point of succumbing with the \\ soot [of the pot], so much she suffered. \\ Child of the wife-givers [Sister-in-law], bring \\ me honey-beer until I feel it.
}

Zempléni's (1977) case study of the medium Khady Fall illustrates how spirits embody dramatic kinship roles. On closer investigation, the spirits came before the roles. They were patterns returning in Khady's life and haunting her. The song above, exposing the haunting 'spirit' of married women, prefigures roles not yet established. Thinking of Stoller's (1989: 19) observation that spirits have throughout Songhay history been in the vanguard of social change by 'incorporating' the names of newly arrived groups, we can imagine mediums to be the most likely source of inventions turned culture. The freedom to subvert conventions at least diminishes the inhibition to explore other structures of experience. I will analyse this exploration after describing 
in unadorned fashion the second part of the initiation. I conclude that novices snap out of a rigidified view of the world with the raising of their capacity to let opposite structures of experience co-exist.

\section{The 'big forest': regaining the senses}

The morning after the rite of kugwisha, which had confirmed everyone's possession by Chwezi spirits, we burned the bundle of grass that our fists had clenched during the séance. We ran in circles spreading the smoke in the central courtyard. This smoke was our spirit, we were told. Then we spoke and sang in the obscene metaphors that had been taught to us the previous days. Unaccomplished mediums are dangerously 'hot' (basebu). On bare feet and with head bent, each of us approached the centre of the compound, where the master of ceremonies sat on the traditional stool covered with a leopard skin and tied with the 'pulling' plant. He weaved the plant into lubuha bracelets and smeared them with the blood of a sacrificed goat and with three types of protective medicine. He tied one around each novice's neck as well as on the left or right wrist and ankle, depending on whether the spirit imposing its call belonged to the paternal or maternal clan. In the coming days the bracelet would itch, smell of blood, and attract swarms of flies. The bracelet binds the carrier to a Chwezi ancestor, but also protects against sorcery to which he or she is vulnerable when leaving the space circumscribed by 'the end'. Together with a hundred or so initiated Chwezi and Chwengele (a subgroup $^{4}$ ) the thirty-two of us lined up to cross 'the outside' (ibaala) and meander through the fields to reach the forest.

In half a day, until sunset, we covered all the stages of 'the big forest' ( $b u$ nghale) where 'secrets' (ma-banga) were taught. The teachers completed the training sessions by anointing our bodies with the black residues of burnt groundnuts, as dry and earthly as death. Before that, we had come to appropriate the chief-plant of the cult ritually. It suffices to say that its outlook and name refer to immortality and to the correct term for greeting a king. A month earlier, King Kaphipa of Bukumbi chiefdom had recounted to me how he had been installed as a king fifty years ago. His father's dignitaries had abducted him at night to bury him alive, and were, in his own words, acting like sorcerers. The commoner could turn king through a subversion of social order, whereby death, evil, and sorcery were incorporated rather than expelled. The Chwezi novices are also abducted to perform a subversion of the social order. Could the enthronement ceremony of the old Chwezi dynasty have been an inspiration? Finally, transformation was the grand notion with which we left the forest uplifted and sang the medium's anthem about ancestors lifting their curse while our newly found state of mediumship would never die.

The ritual stage of the 'big forest' helps the novice to overcome his or her inhibition to embrace the announcing spirit, an inhibition understandable from the Sukuma aversion to loss of self-control (for which I have seen Pentecostalists in town ridiculed). As the next song reveals, once the gaze of the other no longer inhibits, nothing can stand in the way between the medium and his or her fate.

\footnotetext{
Baana baneye, nalekelwa izumo. $\quad$ My children, I have left the curse behind. Nyanjige, nabi liiso lukuni. Nyanjige, I have become clairvoyant.

Uku nzila nduhu ihamo, uku Welelo. On the road lies nothing, but fate.

Ukubyala, namala. Ninga. To give birth, I finished. I have come out.

Ukusekwa na banhu. To be laughed at by people.

Nabi liiso lukuni. I have become clairvoyant.
} 
The next day teacher and novice spend together in making the shishingo diadem from the root of the chief-plant. On the root the teacher sows several rows of cowries opening vertically, like female genitals, and towards the sky. The black tail of a bushbuck antelope (mbushi) is connected at the back. Thus the pupil obtains an oblong diadem extending from the middle of the forehead to the fontanelle (manda), where the spirit enters before descending to the spine.

During the fourth night, the ritual procedures followed each other closely. First the teachers made an end to our unaccomplished ritual condition (kumelamela). In the pitch dark we were brought to an intersection, where each novice sat on the ancestral seat and received medicinal incisions on the chest and on top of the head. The teacher then turned his back on the pupil. His little fingers reaching for the pupil's, the latter was lifted up while his or her right foot toppled a cooking pot covered with a jackal hide. In other Sukuma societies, too, this movement signifies accomplishment of initiation. The teacher addresses the novice with the words: walijiwa badugu, 'you have been eaten by the ancestors'. In daily life 'to be eaten' is an ominous expression, referring to occult appropriation and lethal indebtedness. But here all cult members are equally 'eaten' by their spirit. Healing becomes a life-long journey, one that even the malamala, the 'completing one', admits never having finished:

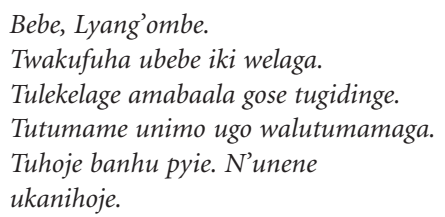

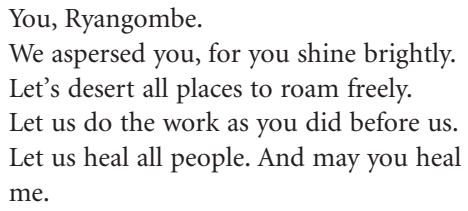

With their former selves dead and having been consumed by the spirit, the newly initiated are ready to regain their senses. This must be taken literally. They move into the forest, this time at night ( $k u$ mabuga), to consecutively taste the spirit, smell medicinal vapours, and feel on their skin the soil of the ancestors. At the termitemound, which represents the ancestral realm, they first make a vow on the tomb of their cult parents and grandparents. Then, lying down at a tunnel dug at the base of the termite-mound, they wait for Ng'wana Kapini to take a mouthful of flour-mixture and asperse them. Still lying down, the newly initiated drink from the water at the base of the termite-mound, thus ingesting the ancestor. They perform the opposite of aspersions placating the ancestors. Each of the Chwezi seniors (bagogo) chooses a novice as his child. Parents and children then symbolically enact copulation, which, as the reader may have gathered, is in 'the spirit' of the cult not a transgression of the incest prohibition, but a negation of the existence of that prohibition. They act just as the spirits do.

The tunnel is destroyed and the group returns to the compound in euphoria. They have performed 'convulsions in the forest' (kugalagala mu bu). Preparations are underway for the two final stages of the therapy: fumigation (luhiga) and mud massage (lutaka). Small groups of patients take turns around a pot of medicinal water dug in the ground. Boiling-hot hearthstones are dropped in the pot and a large cloth is placed over groups of patients inhaling the steam released. Soon after, the heat is alternated with the utter coldness of a mud massage. For the rest of the night the patients dance topless in a circle while being covered all over with fresh mud, made of cow-dung, wet soil, and herbs. The other members help them through this ordeal with moral support, songs, and drumming. The Chwezi compare the mud to the flour-mixture with which healers 
asperse their ancestral altars. On top of the bodily sensation of contrast, the mud massage turns the medium into an altar for the ancestor.

By sunrise the initiands, shivering with cold, line up to leave the ritual space of the compound. At the exit each of them jumps over a black cloth covering the master-tier of bracelets. From there the whole group continues down to the water-pond to bathe (ha lyoga) and collect their diadem from the shigiti tree, which stood in the central courtyard. The malamala pronounces the final formula.

\begin{tabular}{|c|c|}
\hline $\begin{array}{l}\text { Abakoyiwagwa buChwezi } \\
\text { twabumalaga. }\end{array}$ & $\begin{array}{l}\text { Those who had Chwezi trouble, } \\
\text { we ended that. }\end{array}$ \\
\hline $\begin{array}{l}\text { Bahole, babyale, bitombe, bapone, } \\
\text { basabe, balagule. }\end{array}$ & $\begin{array}{l}\text { Let them heal, give birth, have sex, harvest, } \\
\text { enrich, cure [others]. }\end{array}$ \\
\hline
\end{tabular}

Guards will accompany the novice home, where millet stalks (ibelile) inserted in the roof and an altar of 'remainders' (misagati) will remind them of a small follow-up ceremony to be held later on. The little round construction of wooden sticks diverging towards the sky perfectly inverts the domesticating inclination of the clan's ancestral altar, which closes on top.

\section{Conclusion: structures of experience}

The anthropologist's search for structure in the amalgam of experience continues a post-Kantian tradition: Wittgenstein's language games, Dewey's experiential structures, Schutz's life-worlds, Goffman's experiential frames, Bateson's metacommunicative frames, to name a few. The reality of opposite structures, explaining genuine shifts of mood and perception, became visceral to me the day our initiatory rites were interrupted by memorial services held for a deceased leader (see right column of Table 1 for the memorial's chronology). Halfway through the sacrifice of the goat representing the deceased, the women were suddenly chased from the house with the words: 'This is a funeral!' That little it took before the Chwezi mood had receded and people sensed during mourning that the village rules were back in order, in this case with regard to sexual separation. Another example is the sharp discussion I witnessed during a meeting when someone proposed not to treat novices unable to pay the fees. One tall elder stood up and gained approval when protesting in a carrying voice: 'This is not business but your ancestral spirit. There is no leader in spirit matters' (Iti biashara, isamva lyako duhu. Ati ntale mu isamva). He thus conveyed his awareness of logics conflicting. Have the novices come there to heal, or to attain Chwezi status (hence 'business'), or because the spirits want it?

Table 1 schematizes the ritual in terms of these three alternating logics: the ritual passage to healing and initiation (left column), the members' concerns over status and power (right column), and the contingency of possessions taking place at night (italics). The ritual passage has the chronology of a day-cycle stretched over at least five days. At sunset the blindfolded magician demarcates the ritual space; at noon the initiands are dropped into a symbolic void to reach the spirit; in the afternoon and at night they regain their senses; at sunrise their new life commences. We recognize the classic dialectic of rebirth. The cycle is structured by the paradigm of healing. Nothing is said still of possession proper. Indeed, the chronology unfolds in tension with its opposite: the unpredictable moments when the spirit overtakes, mostly at night.

If no ritual can command the spirit, how can possession be initiated? The paradox is symbolized in a straightforward inversion of the clan's ancestral altars. Equally 
Table 1. Chronology of the Chwezi rites in terms of therapeutic initiation (left column), cult activities (right column), and nocturnal spirit possessions (italics).

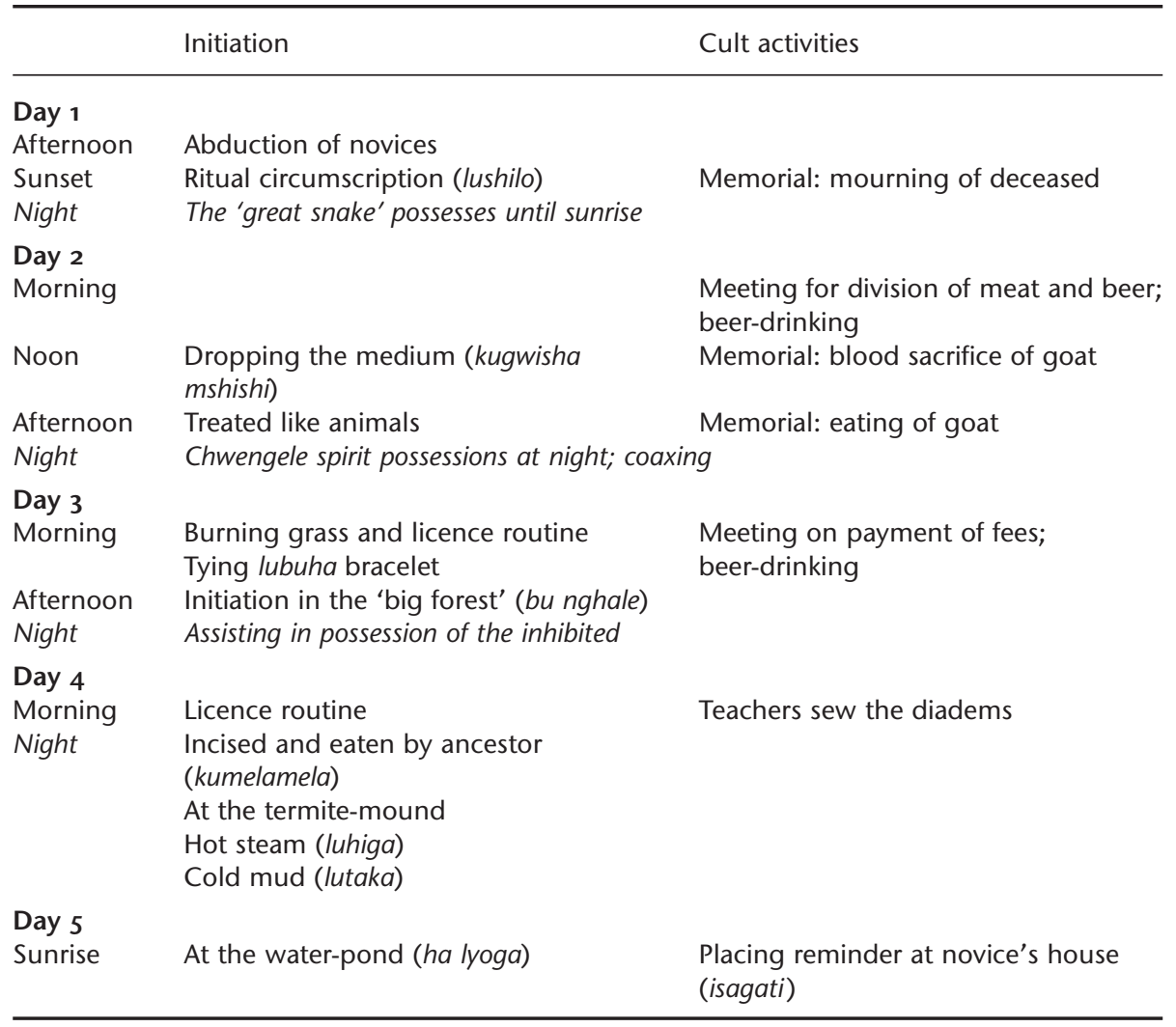

indicative is the contrast with the village initiation called ihane for membership into the society of elders (bunamhala). There the young men become accredited as 'feathers of the Sukuma wing', to obey the laws of clan and community so that ancestral spirits inhabit the domestic altars and do not roam freely (Stroeken 2002: 105). In contrast, Chwezi initiation does not stimulate the slightest interest in reintegrating spirits, let alone the novices, into village life. The cult typically negates gender division and village rules.

And yet, the Chwezi know they are not witches. Therefore they publicly insist on the dialectic of healing. The price, however, is for outsiders (perhaps ethnographers too) to mistake the spirit for a healer, that is, for a source of therapy instead of the very denial of therapy. Bugeke's child suffered and sang that 'the mind goes on speaking'. But 'it has become mine', she added, opting for the shock of possession as a way of life. She discovered a logic that sets an 'end' (lushilo) to the bewitching dialectic of social redress, which healing too sustains. She would live on with her shishingo diadem, as it opens up to the spirit and connects her to a world without prohibitions or selves to feel guilty or envious about.

Mediums (and perhaps mystics too) exhibit at the moment of spirit intrusion a detachment from the social order, the very experience that patients diagnosed with bewitchment are incapable of. The comparison is not entirely new. Michael Lambek 
(2003: 201) recently contrasted the witch and the medium, associating them with self-loss and self-expansion, respectively (and with the psychoanalytical opposites of projection and introjection). As in my remark on de Heusch's exorcism/adorcism, an experiential approach, however, tells us to break through the symbolic dualism. 'The witch' is not a person who could be contrasted with the medium, but an idea structured by someone's experience of crisis. To compare like with like, the experiential structure of bewitchment should be our starting-point, just as it is for diviners (see Stroeken 2004: 47). While bewitchment means self-loss, the use of magic is normal selfexpansion, which Sukuma are supposed to engage in ('like good dancers') for social order to be liveable. Mediumship, then, I deduct from the Chwezi ritual, refers to yet another experiential structure than the expansion versus self-loss around which magic, bewitchment, and healing revolve. The initiated Chwezi learn that people normally enjoy social order, that bewitchment may breach it, that the order can be restored through remedy, but that possession is neither of these three. An inclusive (quaternary) experience is suggested that explains the sense of superiority I know many mediums to combine with their tragic state of affliction.

Most Chwezi return to their daily chores as farmers without pursuing a career as medium-healer. But they will keep on meeting. One never gets rid of the call. And they admit to feeling nostalgic (ilundu) about the cult's specific ambience which helped them to snap out of a rigidified experience of the world. More than in any other social domain, there is a stimulation of the participant's capacity to let experiential structures co-exist. That is how the initiation can be therapeutic. On the last day I casually conversed with a fellow participant unable to utter a word the week before. I speculate that even severe psychical disorders can benefit from Chwezi subversion. Bateson (1990 [1972]: 190) defines schizophrenia as an inability to set meta-communicative frames and to take metaphors other than literally. Teasing such multiple structures back into the novice's picture, do the Chwezi rites not replicate, in a more refined way, the psychotic's survival reflex of hallucinatory perception?

Stalking the stalker is, with all its political and medical implications, the refusal to reduce crisis to manageable proportions. What the spirit mediums cherish about possession is not so much the physical event of trance or the possible content of their shrieks (the name of a spirit) but the arrival of that symbolic 'void' amidst their social reality. The void intimates a complexity easily overlooked, just as avant-garde music seems 'noise' (Attali 1985) to the establishment. Whereas ritual socializes and conveys meaning through a ternary code (and communication conveys meaning through a binary code, see Luhmann 1989: 36), possession has the (quaternary) complexity of bringing home the gap between meaning and subjective experience. Of course, the dialectic of social resistance which could follow from this revelation of the subject's indeterminacy is less relevant in Sukuma communities than in more oppressive settings. Here we inevitably think back to Boddy's cited work on the many Sudanese women reasserting their selves through possessions in public. They give proof of a heightened sensitivity to the gap, whereas restoring the social order would only worsen their crisis.

Possession is a moment of synchrony with something deeply intrusive. This quaternary structure of experience applies to such diverse cases as spirits embodying Muslim hegemony (McIntosh 2004) and spirits supporting millenarian hopes (Csordas 1995). After seeing a Chwezi drummer from Mwanza substituting his hip-hop cap for the diadem, it seemed to me but a small step to the subversion expressed in Tanzania's 
famous hip-hop scene called Bongo Flava, 'brain flavour'. The rappers immunize themselves to an intrusive reality called 'the real situation', hali halisi, by imparting it, thus subversively embracing it, instead of what society expects (Stroeken 2005: 505). The music has everything of an articulate form of speaking-in-tongues magnifying the gap between dominant codes and subjective experience. What else could the rapper's claim of 'seeing far' intimate but a privileged feel for the gap? That sensitivity I have argued to be the spirit medium's. To repeat the anthem, Chwezi initiation lets newcomers experience what in mediumship 'does not die'.

\section{NOTES}

My deepest gratitude goes to Paulo Makufuli, Sele Lukundula, Ng'wana Hande, and Ng'wana Kapini, for choosing to train me. Heartfelt thanks are due to René Devisch and Per Brandström, who advised me during fieldwork, as well as to Wim van Binsbergen, Murray Last, and Michael Lambek for their comments at workshops respectively in Leuven, Norderney, and Leiden. The research was carried out under a grant from the Fund for Scientific Research in Flanders.

${ }^{1}$ In central Sukumaland, where I worked, the group is pronounced 'Chweeji', but to facilitate reference I opt here for the term common in written records. 'Chwezi' (sometimes spelled Cwezi) is used where the cult's origins lie, northwest from Sukumaland (Bjerke 1986). In the southern (Dakama) vernacular, Sukuma speak of 'Swezi' (see Cory 1955).

${ }^{2}$ The lyrics go: 'We and the Galu, let's make peace. We and the Gika, let's make peace. It's all kin. We are from the west' (Bise n'unGalu, twiholele. Bise n'unGika, twiholele. Shene shibyalilwe. Tuli bang'weli). In pretending to be 'kin' to both affiliations and in relating this improbable kinship to a 'western' (bang'weli) belonging, again a quaternary structure is carved out: between day (social order) and night (the occult) and opposed to the east, where the sun rises and society's origins lie (such as the great divination traditions), is situated the west, where the sun sets and utter novelty resides (kingship in the past, new kinds of magic today).

${ }^{3}$ The spirit's idiom has served different, opposite purposes. De Heusch (1966: 353 ) insightfully applied the Chwezi revolutionist idiom to the changes in Rwanda after the 'Manifeste des Bahutu' in 1957 and during the 1960 s when the success of national government and church in forbidding the cult yielded its fruits: effective violence against the Tutsi substituted for the cult's mystical forces. Two generations later, in the aftermath of the genocide in Rwanda and Burundi, tendentious reports on the Congo crisis and the role of Banyamulenge suggest 'a Tutsi scheme to resurrect the Chwezi dynasty', whereby those immortal spirits found a new home for their past to come to roost (see Nabudere 1998).

${ }^{4}$ Among the thirty-one entering the cult with me, there were five Chwezi and the rest were Chwengele. The Chwengele form a sub-group, with a smaller initiation fee, skipping some of the rites and focusing on collective séance sessions. The years before and after, owing to better harvests, record numbers of more than eighty participants entered in one go in both groups.

\section{REFERENCES}

Aвrahams, R.G. 1987. Sungusungu: village vigilante groups in Tanzania. African Affairs 86, 179-96.

Attali, J. 1985. Noise: the political economy of music. Minneapolis: University of Minnesota Press.

BAteson, G. 1990 [1972]. Steps to an ecology of mind. New York: Ballantine.

Berger, I. 1981. Religion and resistance: East-African kingdoms in the precolonial period. (Annalen Menselijke Wetenschappen 105). Tervuren: Koninklijk Museum voor Midden-Afrika.

BJERKE, S. 1986. Witchcraft as explanation: the case of Zinza. In Culture, experience and pluralism: essays on African ideas of illness and healing (eds) A. Jacobson-Widding \& D. Westerlund, 219-34. Stockholm: Almqvist \& Wiksell.

BoDDy, J. 1989. Wombs and alien spirits: women, men and the Zar-cult in northern Sudan. Madison: University of Wisconsin Press.

1994. Spirit possession revisited: beyond instrumentality. Annual Review of Anthropology 23, 407-34.

Bösch, F. 1930. Les Banyamwezi, peuple de l’Afrique Orientale. Münster: Biblioteca Africana.

Bourdieu, P. 1980. Le sens pratique. Paris: Minuit.

Bourguignon, E. 1973. Introduction: a framework for the comparative study of altered states of consciousness. In Religion, altered states of consciousness, and social change (ed.) E. Bourguignon, 3-35. Columbus: Ohio State University Press. 
Comaroff, J. 1985. Body of power, spirit of resistance: the culture and history of a South African people. Chicago: University Press.

Cory, H. 1955. The Buswezi. American Anthropologist 57, 329-52.

Crapanzano, V. 1977. Introduction. In Case studies in spirit possession (eds) V. Crapanzano \& V. Garrison, 1-40. New York: John Wiley.

Csordas, T. 1995. The sacred self. Berkeley: University of California Press.

Devisch, R. 1993. Weaving the threads of life: the Khita gyn-eco-logical healing cult among the Yaka. Chicago: University Press.

FernandeZ, J. 1991. Embodiment and disembodiment in Bwiti. In Body and space: symbolic models of unity and division in African cosmology and experience (ed.) A. Jacobson-Widding, 315-34. Stockholm: Almqvist \& Wiksell.

Giles, L. 1987. Possession cults on the Swahili coast: a re-examination of theories of marginality. Africa 57, 234-58.

Goffman, E. 1974. Frame analysis: an essay on the organisation of experience. Harmondsworth: Penguin.

Good, B. 1994. Medicine, rationality, and experience: an anthropological perspective. Cambridge: University Press.

HeusCh, L. DE 1966. Le Rwanda et la civilisation interlacustre. Brussels: Université Libre de Bruxelles.

1971. Pourquoi l'épouser, et autres essais. Paris: Gallimard.

JACKson, M. \& I. KARP 1990. Introduction. In Personhood and agency: the experience of self and other in African cultures (eds) M. Jackson \& I. Karp, 15-30. Stockholm: Almqvist \& Wiksell.

KAPferen, B. 1997. The feast of the sorcerer: practices of consciousness and power. Chicago: University Press.

LAмвек, M. 1981. Human spirits: a cultural account of trance in Mayotte. Cambridge: University Press.

2003. Fantasy in practice: projection and introjection, or the witch and the spirit-medium. In Beyond rationalism: rethinking magic, witchcraft and sorcery (ed.) B. Kapferer, 198-214. New York: Berghahn.

LEWIS, I.M. 2003 [1971]. Ecstatic religion: an anthropological study of shamanism and spirit possession. London: Routledge.

Lienhardt, G. 1976 [1961]. Divinity and experience: the religion of the Dinka. Oxford: Clarendon.

Luhmann, N. 1989. Ecological communication. Cambridge: Polity.

McIntosh, J. 2004. Reluctant Muslims: embodied hegemony and moral resistance in a Giriama spirit possession complex. Journal of the Royal Anthropological Institute 10, 91-112.

Métraux, A. 1972 [1959]. Voodoo in Haiti. New York: Schocken.

Nabudere, D. 1998. Kabila's war: chickens coming home to roost. The Sunday Monitor, 30 Aug., 1.

Sharp, L. 1999. The power of possession in Northwest Madagascar: contesting colonial and national hegemonies. In Spirit possession, modernity and power in Africa (eds) H. Behrend \& U. Luig, 3-19. Madison: University of Wisconsin Press.

Stoller, P. 1989. Fusion of the worlds: an ethnography of possession among the Songhay of Niger. Chicago: University Press.

Stroeken, K. 2002. From shrub to log: the ancestral dimension of elderhood among Sukuma in Tanzania. In Ageing in Africa: sociolinguistic and anthropological approaches (eds) S. Makoni \& K. Stroeken, 89-108. Aldershot: Ashgate.

2004. In search of the real: the healing contingency of Sukuma divination. In Divination and healing: potent vision (eds) M. Winkelman \& P. Peek, 29-54. Tucson: University of Arizona Press.

2005. Immunizing strategies: hip-hop and critique in Tanzania. Africa 75, 488-509.

Tcherkézoff, S. 1985. The expulsion of illness or the domestication of the dead: a case study of the Nyamwezi of Tanzania. History and Anthropology 2, 59-92.

Turner, E. 2004. Drumming, divination, and healing: the community at work. In Divination and healing: potent vision (eds) M. Winkelman \& P. Peek, 55-80. Tuscon: University of Arizona Press.

Van Binsbergen, W. 1991. Becoming a Sangoma: religious anthropological fieldwork in Francistown, Botswana. Journal of Religion in Africa 21, 308-44.

VAnsina, J. 2004. Antecedents to modern Rwanda: the Nyiginya kingdom. Madison: University of Wisconsin Press.

Werbner, R. 1989. Ritual passage, sacred journey: the process and organization of religious movement. Washington, D.C.: Smithsonian Institution Press.

Willis, R. 1999. Some spirits heal, others only dance: a journey into human selfhood in an African village. Oxford: Berg. 


\section{Koen Stroeken}

Zempléni, A. 1977. From symptom to sacrifice: the story of Khady Fall. In Case studies in spirit possession (eds) V. Crapanzano \& V. Garrison, 87-139. New York: John Wiley.

\section{«Guetter le guetteur » : initiation à la possession par les esprits et structure d'expérience chez les Chwezi}

Résumé

Chez les Sukuma de Tanzanie, la société spirite des Chwezi œuvre dans l'ombre des cultes lignagers qui domestiquent les morts, et dans une relation de tension avec ceux-ci. Comme le décrit la présente étude ethnographique, les aspirants Chwezi sont initiés à la possession par les esprits en "guettant le guetteur ", c'est-à-dire en cherchant à se synchroniser avec l'intrusion. Bien qu'elle ait, en son temps, tiré l'anthropologie de sa crise de représentation, la reconnaissance de la guérison et de la puissance (ou résistance) dans les performances spirites empêche aujourd'hui de progresser. De fait, ces deux fonctions occultent la possession en tant que telle, alors que celle-ci, à la différence des rituels, possède une structure subversive, " quaternaire ", qui révèle le fossé entre expérience et communication et décentre ainsi à la fois l'individu et la société. La possession par les esprits met en évidence la pluralité des structures d'expérience. Cela pourrait mieux expliquer son rôle, partout dans le monde, dans la dialectique de la résistance sociale et de la guérison cathartique.

Koen Stroeken is a Postdoctoral Fellow of the Research Foundation Flanders (FSR) and teaches at the University of Leuven. His fieldwork among Sukuma farmers in northern Tanzania concentrates on medical anthropology, consciousness, and the critical imagination in popular culture.

Department of Social and Cultural Anthropology, Tiensestraat 102, 300o Leuven, Belgium. Koenraad.Stroeken@ ant.kuleuven.be 